\title{
Informational behaviour in Facebook focused on Brazilian popular music (BPM)
}

\author{
Célio Andrade de Santana Júnior* \\ Steffane Ramires de Lima**
}

Artículo recibido:

24 de marzo de 2018

Artículo aceptado:

24 de enero de 2019

Artículo de investigación

\section{Abstract}

This study was conducted to investigate the information behaviour of Facebook users that follow a fan page focused on Brazilian Popular Music (BPM). The conceptual framework used was Wilson revisited model for information behaviour. Qualitative research was conducted in two steps. i) First, a netnography of users on the page "com açucar, com afeto" in Facebook was conducted to find patterns of collective behaviour, and specific actions and ii) an interview with 32 users was performed to collect data about their perception. The netnography revealed collective behaviours when observing shares, likes,

* Departamento de Ciência da Informação, Universidade Federal de Pernambuco, Brasil

celio.santana@gmail.com steffane.ramires@gmail.com

INVESTIGACIÓN BIBLIOTECOLÓGICA, vol.33, núm. 80, julio/septiembre, 2019, México, ISSN: 2448-8321 pp. 13-30 
and comments, it helped to discover in which posts, authors or even content is more popular and how the users react to each post. The users of Facebook page "Com açucar, com afeto" fill the emotional and cognitive needs of its visitors; initially, users look to the page due the interest in BPM, but the use of the page evolves to fill emotional and cognitive needs to share experience based on feelings and emotions brought by music. Three intervening variables appear as the most significant in the information behaviour of users: i) Psychological, ii) Social and interpersonal role and iii) the environment itself.

Keywords: Facebook; Information Behaviour; Brazilian Popular Music.

El comportamiento informativo en Facebook centrado en la música popular brasileña (MPB)

Célio Andrade de Santana Júnior and Steffane Ramires de Lima

\section{RESUMEN}

Este estudio se realizó para investigar el comportamiento de la información de los usuarios de Facebook seguidores de una página dedicada a la música popular brasileña (MPB). El marco conceptual utilizado fue el modelo revisado de Wilson para el comportamiento informacional. La investigación cualitativa se desarrolló en dos pasos: 1) se elaboró una netnografía de usuarios en la página "Com açucar, com afeto" en Facebook para encontrar patrones de comportamiento colectivo y acciones específicas y 2) se entrevistó a treinta y dos usuarios para recopilar datos sobre su percepción. La netnografia reveló comportamientos colectivos al observar acciones compartidas, "me gusta” y comentarios; asimismo ayudó a descubrir en qué publicaciones, autores o incluso contenido es más popular y cómo reaccionan los usuarios a cada publicación. Los encargados de la página de Facebook "Com açucar, com afeto" satisfacen las necesidades emocionales y cognitivas de los visitantes; inicialmente, los usuarios miran la página debido al interés en MPB, pero el uso de la página evoluciona para satisfacer las necesidades emocionales y cognitivas para compartir experiencias basadas en los sentimientos y 
las emociones que genera la música. Las tres variables intermedias aparecen como las más significativas en el comportamiento de la información de los usuarios: a) psicológica, b) papel social e interpersonal y c) el entorno en sí.

Palabras clave: Facebook; Comportamiento Informativo; Música Popular Brasileña (MPB).

\section{INTRODUCTION}

Tn 1997, the mix of music and Internet launched its first "hit singles" when Winamp ${ }^{1}$ audio player became one of the most downloaded software in history and the website MP3.com reached the mark of 2 million downloads per day. Two years later, Napster.com became the reference of music sharing service on the Internet. In 2001, Napster had 24.6 million users exchanging files simultaneously (Burgess, 2014: 30).

Napster affected all productive chains of the music industry including artists, record companies, and consumers. Some of them took advantage of the "free" publicity to improve their marketing; for example, the band Radiohead, that never reached top 20 in singles, had the top 1 album sales after Napster shared promotional content before launching (Menta, 2000). Napster lost the legal battle against record companies and shut down his services in July 2001. Vaccaro and Cohn (2004: 48) believe that Napster had distributed more music than any record company at that time.

The partnership between Music and Internet was still a success in 2003 when Apple launched its iTunes service. In 2012, iTunes became the most profitable store on Internet, and $52 \%$ of the media sold there were songs. In 2013, Youtube became the fourth most accessed website in the world, and about $50 \%$ of the visualizations were related to music representing a new form of relationship between artists and public (IFPI, 2015).

In virtual social networks, the process of search content of interest seems to be a bit different from the one performed in other Internet environments. From this perspective, the motivation of this research is to identify characteristics of the information behaviour of users when using

1 <https://web.archive.org/web/20060720214602/>,<http://www.cnet.com/4520-

111com/4520-11136_1-6257577-1.html>, accessed in 10th August 2018. 
virtual social networks to share information about music. The purpose of this paper is to present the search about the information behaviour of users of the page "Com açucar, com afeto" on Facebook. This page congregates people interested in Brazilian Popular Music (BPM).

\section{Theoretical BACKground}

\section{Web Information Behaviour}

Case (2012: 41) states that the Internet represents a metaphor of how information behaviour and our understanding of it has changed. The differences are not related only with the variety of channels providing information. Now, everything is in the browser, but lesser goal-oriented behaviours emerged, such as browsing, and these may play a larger role in the Internet environment. Now, looking for information becomes more holistic.

The use of Internet as an information source is increasing. Fisher $e t$ al. (2005) state that general people involve the Internet in their informational grounds more frequently. The Internet is used as a source of information for $39 \%$ of the surveyed people while $2 \%$ is still going to a library. Kaye and Johnson (2003: 261) suggest that the Internet is gradually substituting other media usage particularly television, radio, and magazines.

Savolainen (2004) identified three groups of users when they are using the Internet as a source of information. i) The enthusiastic ones see the web as an excellent tool that allows freedom, and it becomes their first-choice for information services. ii) The realistic ones see the Internet as one more option which is strongly dependent on particular situations and contexts. The last ones iii) are the critical ones that see Internet as a space containing little amount of relevant information and is poorly organized, which make information seeking hard to perform.

Huberman et al. (1998: 96) proposed a mathematical model called "law of surfing" that "determines the probability distribution of the depth - that is, the number of pages that one user visits within a website". This model is based on the probable number of links a user might follow on a website. The value of the current page is calculated and related to the next page accessed and it seems useful to examine the cost of continuing surfing. When the cost 
of moving to the next page is more than expected, the user stops surfing. Knight (2007: 76) developed a theoretical model (Figure 1) about how people retrieve information on the World Wide Web. She considers the behaviours of seeking and searching (using engines like Google) are different due to the specific needs, activities and results expected for each one of these tasks.

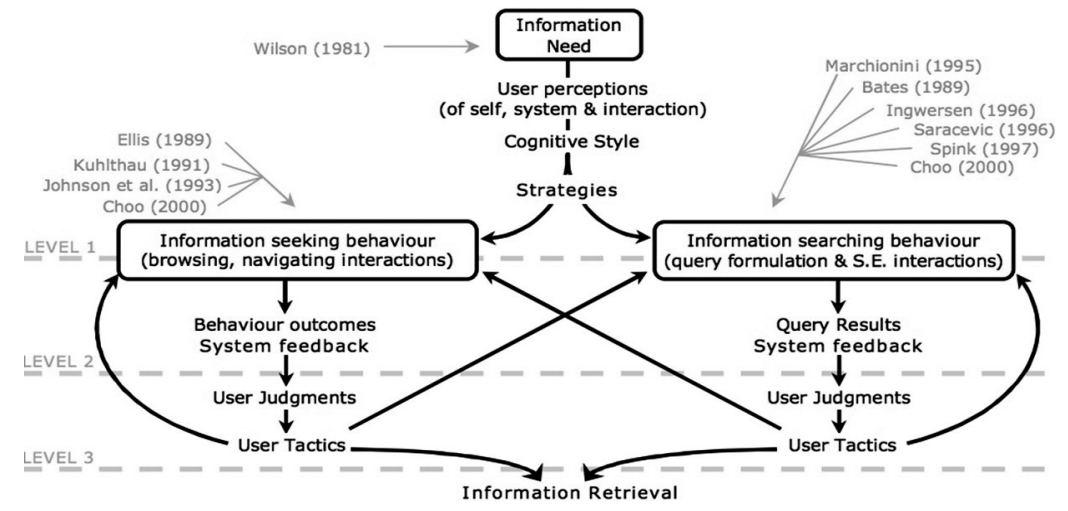

Figure 1. A macro model of human information retrieval behaviour on the WWW (Knight, 2007).

\section{Music Information Seek}

Case (2012: 55) states the blind spots in information seeking studies that raise the "artificial" distinction between entertainment and information. "Part of this bias against entertainment undoubtedly comes from our tendency to over-rationalize human behaviour. We prefer to see people primarily as thinking beings." Cermak (1996: 124) corroborates stating that: "although information and entertainment may be conceptually distinct, from a practical point of view, they are hopelessly entangled. One would be hard-pressed to name a vehicle for delivering information that is not also used for providing entertainment" (Cermak, 1996: 124).

Allen (1996: 52) states that musical information needs are entirely different from those one involving other formats, especially text. The cognitive discourse about information behaviour, considers information needs regarding problem-solving, where knowledge gaps are solved by potential outcomes. Laplante and Downie (2011: 2003) think that the concept "problem-solving" works well for systems based on text-retrieval, which is different to music-retrieval. The reason for this difference is the fact that searching and browsing behaviour are based on affective rather than cognitive needs. 
Laplante and Downie (2006: 32) point two characteristics of musical information behaviour of young people: i) they consider informal channels such as friends, colleagues or relatives are important sources of information. ii) Music information seeking is a non-goal oriented activity, and these young people prefer browsing instead of searching.

Carlisle (2007) suggests that musical information behaviour can change depending on the kind of music that people are searching. She found three kinds of public presenting different behaviour: i) Romantic Repertoire Fans, ii) Culture Repertoire Fans and iii) Multi-Cultural Repertoire Fans. In this new light, Neal and Conroy (2012) state that musical information seeking has tended to follow a system-oriented rather than a user-oriented approach. System-oriented tends to be concerned with the development of the content-based features, automatic content analysis and classification.

Clarke et al. (2010: 51) present some underlying motivational triggers that affect musical information behaviour such as: i) social engagement and bonding, ii) help on extra-musical tasks, iii) identity construction and iv) mood management. Neal and Conroy (2012) points to three challenges concerning musical information behaviour: i) descriptions of music are complex, ii) music search is social, iii) how to catalog personal music collections.

Clarke (1973: 551) investigated how teenagers share information about music. He made a distinction between information seeking, involving sources outside one's social system, and information sharing, in which verbal and nonverbal information is exchanged within a social group, rather than deliberately sought out. Clarke concludes that measuring the frequency at which people listen to music does not seem to be a good predictor of musical information seeking as the number of pairs that these people share music. Clarke also concludes that sharing and seeking are more appropriate labels for human behaviour in this context than the more typical discussions of media such as "flows" and "power relationships".

\section{Wilson Revisited Model}

Case (2012) points that Wilson Revisited Model brings a perspective about the complexity of the context of information seeking. According to this author, Wilson identified factors that were also observed in other fields such as "decision making, psychology, innovation, health communication and consumer research". This model is represented on Figure 2 below: 


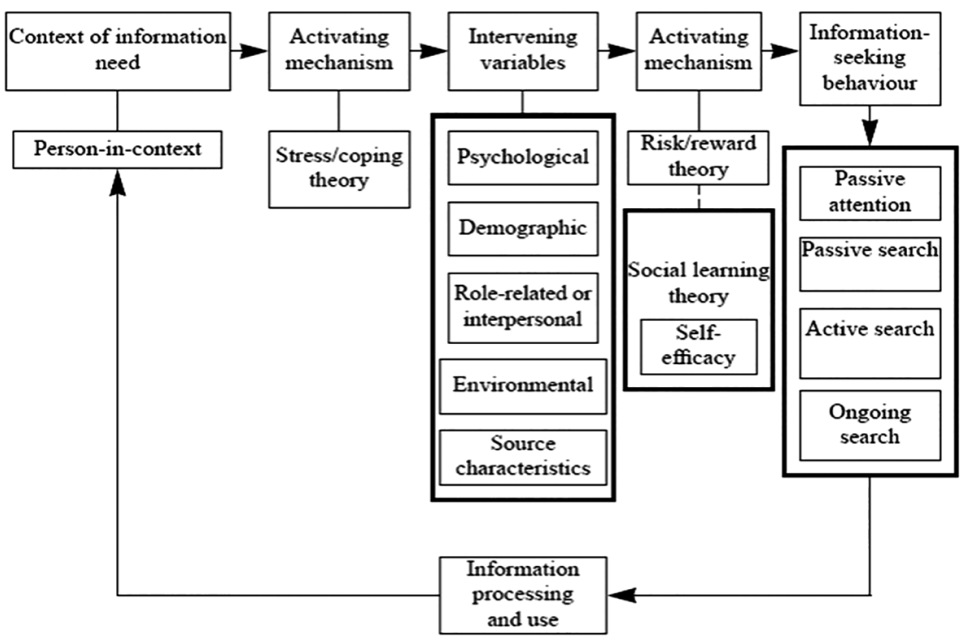

Figure 2. Wilson Information Behaviour Model (Wilson, 2000).

Case (2012) suggests Wilson was trying to disclose three aspects of information seeking:

1) What drives you to post, like, share, or comment the content page?

2) How do you find the content of interest on the page?

3) How do you usually interact with other users?

4) Do you trust or distrust the content generated by someone? Why?

5) How did you find the page? And why do you continue to visit it?

6) How does Facebook interfere in their relationship with the site, or with the people?

Pettigrew et al. (2001) suggest that the context of information need involves an additional question which is: "why does people need that information? and why are they looking for it in that space/support/source?".

Case (2012) explains the flowing two variables:

We might think of Wilson's “activating mechanisms” as motivators: What motivates a person to search for information, and how and to what extent? These motivators are affected by intervening variables of six types: psychological predispositions (e.g., tending to be curious, or averse to risk); demographic background (e.g., age or education); factors related to one's social role (e.g., whether one is acting as a manager or a mother); environmental variables (e.g., the resources available); and characteristics of the sources (e.g., accessibility and credibility). 
An important aspect of Wilson's new model is that it recognizes that there are different types of search behaviors: passive attention, passive search, active search, and ongoing search" (Case, 2012).

\section{Methodology}

This research intends to analyze the information behaviour of the Facebook page users "Com açucar, com afeto". First we collected data by netnography, or ethnography on the Internet, which is a qualitative research method that adapts ethnographic research techniques to the study of emerging cultures and communities through computer-mediated communication (Kozinets, 2001). In this first moment, we were interested in the collective behaviours and tried to find patterns that answered some of the Wilson revisited model questions. We used our own Facebook interface to collect information on each post and identify likes, shares, and tagging and commented numbers and who performed each action. To each post, we also obtained song related data such as the song, singer/band and album. The netnography took place from March 2013 to March 2014.

All these data were stored in Excel spreadsheets, and a quantitative analysis of each post was performed. Initially, we related the number of interactions (likes, shares and comments) with musical data (singer/band, song and album). Our intention was to find patterns or preferences that could indicate "more propitious" conditions to attract the attention of the community. The analysis indicated that the amount of interactions with the post was more related to the moment of posting than to the content itself. Posts created after 19:00 (GMT -3) had, in average, three times more comments (not so true to likes and shares) than posts created in the morning/afternoon. And mainly, the information collected on the fan page was insufficient to answer all the questions of Wilson's Revisited Model.

We used the same set of posts to find active users that post, comment and like the page. We invited fifty of the most participative users to take part in interviews and 32 of them accepted. Interviews were conducted from May 2014 to August 2014 and contain open dialogs (unstructured) and included the questions suggested by Case (2012):

1) What drives you to post, like, share, or comment the content page?

2) How do you find the content of interest on a page?

3) How do you usually interact with other users? 
4) Do you trust or distrust the content generated by someone else? Why?

5) How did you find the page? And why do you continue to visit it?

6) How does Facebook interfere in their relationship, with the site, or with the people?

For data analysis, we used the Wilson (2000: 53) revisited model to classify the characteristics of the user's behaviour. Each aspect considered by Wilson model was investigated or based on the netnography or the data of interviews. The Wilson revisited model is shown on Figure 2.

\section{Presentation AND ANAlysis OF THE RESUlts}

For organizational purposes, the research results were displayed according to each aspect presented on Wilson Revisited Model (Figure 2).

\section{Context of Information Need}

The social interaction that happens on this page is based on the exchange of experiences among fans of BPM, which are activated from the emotions that music causes on users. It is noticed that from the stimuli provided by the users themselves, emerged a flow of information that triggered personal reactions.

The first posts on this page were directed only to fans of the singer Chico Buarque de Holanda interested in the artist himself. Along that time, the content had been diversifying in its form (from text to image and from image to videos), and in the user's intention. People have externalized different feelings in the interest of new songs and artists, and the content of interest was amplified from songs recorded by Chico Buarque to all BPM. Finally, the user's intention to follow the page was not restricted to discussing music and finding partners, but as a space to share emotions, feelings and musical preferences. 
Activating Mechanism and Stress/Coping Theory

Wilson suggests that for a user to seek any information, he/she needs to be convinced that this is a necessity, and identify which is the informational gap that has to be satisfied. In the page, the experienced situations by each one are uniques, and can trigger a process of anguish, uncertainty, pleasure, euphoria, etc., which helps to identify primary needs of information.

This emotional element, identifying the activation mechanism is, in most cases, to provide, to himself or others, emotions that arise from specific songs. Another identified need was to find other people who shared the same musical interests or similar sensations and create bonds that engage a group of individuals to participate in posts set up by "friends". Sometimes, some cognitive elements emerged in the reflections of users about lyrics that have a high social context, such as dictatorship, family and social inequalities. The construction of such dialogues depends on emotional issues and individual values; however, the level of knowledge about the reality that surrounds each of these contexts suggests a cognitive component on the users of the page.

\section{Intervening Variables}

Wilson classifies the intervening variables into five types: a) psychological, b) demographic, c) role-related or interpersonal, d) environmental, and e) source characteristics. For this research the following aspects of each were observed.

\section{Psychological}

The page in question is a source of information about BPM presenting emotional posts written by the users. Music stimulates feelings, emotions and memories of an individual that are triggered when he-she remembers/listen to a specific song. On this page, this fact is evidenced by posts that explicitly suggest the emotional involvement such as: "What song reminds you of our father?" Or "To whom do you dedicate this song?". 


\section{Demographic}

Through the analysis of "likes" on the page, it was possible to assess the age and geographical location of the "followers". On Nov. 11, 2013, the page had roughly about one hundred and eighty-four thousand seven hundred and sixteen (184.716) people that commented on the group, while one hundred and sixty-five thousand five hundred twenty-six (165.526) users like it. The city with the largest number of users is São Paulo, and the most active age group are youths between 18 and 24 years.

\section{Role-Related or Interpersonal}

On this page, music is an element of entertainment and also a space to reflect on social construction and to create interpersonal ties. Several posts led users to think about various social realities presented in songs. For example, the song "Romaria ("Pilgrimage") of Elis Regina, was the subject of extensive debate, with over two hundred posts about the question of peasant's and farmer's conditions, their way of life, their problems and their reality. Users shared not only opinions but also facts originating from demographic research, news published in the media, and information derived from third sector organisations all of what made this discussion a rich source of information.

Besides raising this critical sense as well as historical, political and cultural knowledge, another social component identified was the formation of groups that have come to interact in real life. Users created fan's clubs where members went together to shows or music workshops as a moment for relaxing and socialization.

\section{Environmental}

Facebook pages delimit what kind of information users can exchange and how they can interact. There is a possibility to share, like or tag friends and make comments on posts users forming a dynamic asynchronous conversation between them. Only on May 11th, 2013, fifty-five (55) new postings were created, resulting in 30,909 likes, 4,552 shares, 745 comments and 88 people tags. Another issue concerning the environment expressed in the interviews was the difficulty in retrieving information posted over two days. 
Users considered this loss of information significant since there is no resource for active search, in 2013-2014 Facebook had no search option. On the other side, some users thought this feature was an element that promoted the creation of new content, even if ephemeral, which keeps users creating new content for the page.

\section{Source Characteristics}

Facebook is a tool of high visibility; however, the content posted on it is unreliable for many reasons, including the disclosure of songs that are still protected by copyrights, which are being published by third parties that are not allowed to do proper distribution. The unreliability of the sources seems not to affect the requests for updates since users already carry an intrinsic identification with the content (music).

\section{Activating Mechanism, Risk/Reward Theory and Social Learning Theory}

Facebook pages had no search content engine or another kind of metadata that helps retrieving older posts of pages turning the virtual search for specific content impossible. The active search for users is the act of exploring the content (browsing) visible to the user at that moment. The users interviewed claim that most of the "relevant" content found by them came from: i) the attendance of the page, and hardly the posts of interest became obsolete or unavailable to the user, or ii) the tagging performed by friends users on songs that they know interest the user.

The "feeds" also play a significant role in passive search because a user receives their updates by any other users registered on the page, or friends who enjoy sharing content posted and are recorded in your feeds updates. All users interviewed claim to have encountered posts showed by friends in their feeds. The theory of risk/reward assesses how and why intervening variables can trigger or block the initiatives for information. In this case, to activate search, the variables have little influence on the method for conducting an active search (browsing). Users feel engaged with browsing content on the page, and if they are happy finding content of interest (psychological variables) or increasing their friend's network (variables social/interpersonal).

Social cognition theory (self-efficacy) suggests that any individual can always produce the necessary results to obtain the desired behaviour. This expression was not observed in the questionnaires or netnography since the unique way for searching content is browsing. What a user can do to force 
the expected content or behaviour is creating posts to encourage participation from other individuals, however, in this case, no search is possible, you can just look to what other users have commented on the post.

\section{Information Seeking Behaviour}

Wilson points out that at this stage the desired information has been found and accepted by the user. On the page, the information of interest can be used for read-only users (lurkers), shared with the network of friends, and liked, commented or even linked to a friend through a tag. Also, according to Wilson, there are four types of search behaviour: a) passive attention, b) passive surveillance, c) active search, and d) continuous search. Table 1 presents observed behaviours for each of these types.

\begin{tabular}{|l|l|}
\hline \multicolumn{1}{|c|}{ Kind of Search } & \multicolumn{1}{c|}{ Results } \\
\hline $\begin{array}{l}\text { Passive attention: the subject does not aim to } \\
\text { seek information, but information acquisition } \\
\text { can occur in several ways. }\end{array}$ & $\begin{array}{l}\text { Occurs from update of "feeds" or tagging } \\
\text { someone. The user is not actively seeking } \\
\text { anything but an update that automatically } \\
\text { appears in the "feed" or tagged in a publica- } \\
\text { tion. This update can hold the attention of a } \\
\text { user. }\end{array}$ \\
\hline $\begin{array}{l}\text { Passive Search: the subject engages in } \\
\text { situations that help him to find relevant infor- } \\
\text { mation and remains attentive to the possible } \\
\text { information that comes. }\end{array}$ & $\begin{array}{l}\text { Occurs when the user decides to follow the } \\
\text { page and, from this very moment, he begins } \\
\text { to receive information from the feed and can } \\
\text { be tagged by other friends. With this behavior, } \\
\text { the user is placed as "willing" to receive } \\
\text { information page. }\end{array}$ \\
\hline $\begin{array}{l}\text { Active Search: The subject is conscious of } \\
\text { information need and performs a search with } \\
\text { perception and intentionally to find the } \\
\text { information. }\end{array}$ & $\begin{array}{l}\text { Occurs when a user perform a search within } \\
\text { the page, some phrase, image, hyperlink, or } \\
\text { specific song. This is done manually and the } \\
\text { user may not know exactly what songs will } \\
\text { find. }\end{array}$ \\
\hline $\begin{array}{l}\text { Ongoing Search: Active surveillance has } \\
\text { already established and a basic framework } \\
\text { of ideas, beliefs and values, and occasio- } \\
\text { nally the search has expanded or viewed its } \\
\text { structure. }\end{array}$ & $\begin{array}{l}\text { Occurs when the user begins to perform a new } \\
\text { search page, once he realizes that this content } \\
\text { meets your informational needs. Based on net- } \\
\text { nographic data 62\% of users who comment, } \\
\text { share and like, do so with relative frequency. } \\
\text { However, the number of identified users } \\
\text { performing this behavior, 818, represents just } \\
\text { over 0.5\% of total users of the page. }\end{array}$ \\
\hline
\end{tabular}

Table 1. Information Seeking Behaviour found on Facebook Page "Com açucar, com afeto".

Figure 3 presents the summarized results of our research in the Wilson Revisited Model structure. 


\section{Discussion}

An initial analysis of the information behaviour of users of the page suggests that people manifests in online world the same needs and habits related to music presented in "offline world." Users show emotional and cognitive needs when they exchange experiences based on feelings and emotions raised by music.

The motivation of users to initially enjoy the page is the main interest in BPM. Most assiduous users become interested not only in the music itself but also mainly in the emotions evoked on themselves and others, the songs and the lyrics. The possibility of sharing feelings, experiences and debate about social awareness give to the people the sensation of ownership of the space as a place to enjoy BPM.

The search for content happens in two ways: i) the passive attention in observing feeds, or content posted by the markings of friends sharing content with a user. Or ii) the continued search for users who visit the page frequently for the content of their interest. The ambience of Facebook had no search engine and presents a limitation for accessing to older posts due to the volume of new postings.

This apparent limitation of Facebook brings a particular dynamic to the page where updates vary from 40 to 60 daily posts and this wealth of new content make the page attractive to a larger number of users. It was found that a minimal amount of users leave traces of his interest in the posts (comments, likes, and shares).

The vast majority of users are lurkers, who just watch the posts without creating any additional information, and therefore cannot indicate clearly the involvement of these users within the page.

Three intervening variables appear as the most significant in the information behaviour of the users of this page. i) The psychological variables suggest that the role of music is a strong emotional component in human lives and this element should also be reflected in the space where music is the protagonist. ii) The social and interpersonal role is another factor that makes this page unique, since some lyrics make users reflect and discuss the society. This interest in music makes users that have a higher affinity to interact with each other even outside the Internet, and develop emotional bonds in the real world. And finally iii) the own environment, Facebook, provides a greater range of content. This ease of finding people which have same preferences, causes users to start generating content on the page and creating networks into it. 


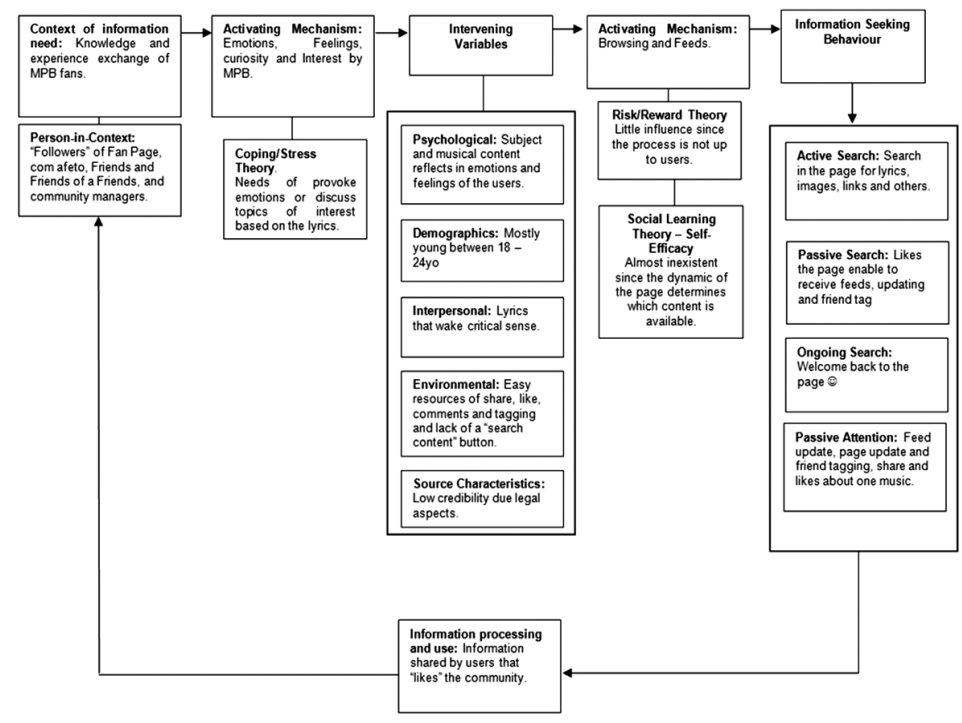

FinAL CONSIDERATIONS

This research presents some threats to its validity that can bring bias to the results. The first internal risk is inherent to the research methods used. Netnography still has an active component of interpretation, even if the data are clear, it is not possible to establish the real reason, and the intention of the users to create a post, like, share and comment. The interview also brings the vision of the respondent on the subject matter bias. Even though it is careful to deal only with the content generated by page users, yet there is a whole building context around the posts that might lead the user to enjoy and share content.

An external threat comes from some respondents (32) of a universe of about 150 million users that can show up as a small sample to determine the behaviour of these. Other external threats to its validity can be related to the period when the netnography and interviews were taken (2013-2014). Since then, Facebook added new functionalities which could change the information behaviours nowadays. Our intention was not to bring the information behaviour of those users in the brand new version of Facebook, but to represent the relationship between social networks, music and information beha- 
viour in a temporal cut, where Facebook had few tools to help users to find specific information. Even though it is hard to deal only with the content generated by it, yet there is a whole building context around the posts that might lead the user to enjoy and share content. The page is still online at Facebook $^{2}$ in Portuguese.

Users come to the page interested on BPM, but usually this motivation drives to friendships and partnership with BPM fans, and some of them share experiences and feelings brought by the songs. They typically browse the page to find posts or comments that enrol them; most of them are engaged with this active search, and some of them use it to tag or be tagged by others.

In the very first moment, the users interact with their Facebook friends. Then, they tend to interact with other users when a specific theme (not the song exactly) emerges. Social causes, political issues or ideological orientations are triggered to recognise people with close interests, and they also feel more comfortable to interact with each other. Most of the users are not worried about the content generated, because they know BPM and the page is moderated to avoid "change of subjects." But none of them was concerned about copyright issues.

The users found the page watching a friend post about it, or by been tagged in a post. But all of them still visit the page because they like to share their feelings with other people that feel similar emotions. These users think that Facebook is a natural environment to find other people with the same interests and share the same culture by expressing themselves in Facebook.

\section{REFERENCES}

Allen, Bryce. 1996. Information tasks: Toward a user-centered approach to information systems. San Diego: Academic Press.

Burgess, Richard James. 2014. The history of music production. Nueva York: Oxford Press.

Case, Donald. 2012. Looking for information: A survey of research on information seeking, needs, and behaviour, 3rd ed. Bingley: Emerald Group.

Carlisle, Justine. 2007. "Digital music and Generation Y: discourse analysis of the online music information behaviour talk of five young Australians". Information Research, 12 (4).

Cermak, Gregory. 1996. "An approach to mapping entertainment alternatives." In Nikhilesh Dholakia and Norbert Mundorf, eds., New infotainment technologies in the bome: Demand-side perspectives, 115-134. New York: Routledge. 
Clarke, Peter. 1973. "Teenagers' coorientation and information seeking about pop music." American Behavioral Scientist, 16, p. 551-566.

Clarke, Eric, Nicola Dibben, and Stephanie Pitts. 2010. Music and mind in everyday life. New York: Oxford Press.

Fisher, Karen, Charles Namuer, Joan Durrance, Lynn Stromski, and Torben Christiansen. 2005. "Something old, something new: preliminary findings from an exploratory study about people's information habits and information grounds". Information Research, 10 (2).

Huberman, Bernardo, Peter Pirolli, James Pitkow, and Rajan Lukose. 1998. "Strong Regularities in World Wide Web Surfing”. Science, 280 (5360), 94-97.

IFBP. 2015. Digital Music Report 2015 - IFBP. Available at <http://www.ifpi.org/ downloads/Digital-Music-Report-2015.pdf>, accessed in 14th July 2017.

Kaye, Barbara, and Thomas Johnson. 2003. "From here to obscurity: Media substitution theory and traditional media in an on-line world". Journal of the American Society for Information Science and Technology, 54 (1), 260-273.

Knight, Shirlee-Ann. 2007. "User perceptions of information quality in World Wide Web information retrieval behavior". Perth: Edith Cowan University, PHD Thesis.

Kozinets, Robert. 2001. "The field behind the screen: using netnography for marketing research in online communities". Journal of Marketing Research, 39 (1), 61-72.

Laplante, A., and J. Downie. 2006. "Everyday Life Music Information-Seeking Behaviour of Young Adults". PHD Thesis. McGill University.

Laplante, Audrey, and Stephen Downie. 2011. "The utilitarian and hedonic outcomes of music information-seeking in everyday life". Library E Information Science Research, 33 (3), 202-210.

Menta. Richard. 2000. "Did Napster Take Radiohead's New Album to Number 1?”. Available at <http://www.mp3newswire.net/stories/2000/radiohead.html>, accessed in 10th July 2017.

Neal, Diane, and Niall Conroy. 2012. "Information behaviour and music information retrieval systems: Using user accounts to guide design”. In Diane Neal, ed., Indexing and Retrieval of Non-Text Information, 83-110. Berlín: De Grutier.

Pe ttigrew, Karen, Fidel Raya, and Harry Bruce. 2001. "Conceptual frameworks in information behaviour". Annual Review of Information Science and Technology (ARIST), 35, 43-78.

Savolainen, Reijo. 2004. "Enthusiastic, realistic and critical. Discourses of Internet use in the context of everyday life information seeking”. Information Research, 10 (1).

Vaccaro, Valerie, and Deborah Cohn. 2004. "The evolution of business models and marketing strategies in the music industry". International Journal on Media Management, 6 (1-2), 46-58.

Wilson, T.D. 2000. "Human information behavior". Informing Science, 3 (2), 49-56.

Para citar este texto:

Andrade de Santana Júnior, Célio y Steffane Ramires de Lima. 2019. "Informational behaviour in Facebook focused Brazilian popular music (BPM)". Investigación Bibliotecológica: archivonomía, bibliotecología e información 33 (80): 13-30.

http://dx.doi.org/10.22201/iibi.24488321xe.2019.80.57931 